\title{
Autocrine proliferating B cells are susceptible to terminal differentiation and apoptosis
}

\author{
Juliane Fluck ${ }^{1}$, Susanne Schachtschneider ${ }^{1}$ and Hinrich \\ Abken $^{1,2}$ \\ 1 Zentrum für molekulare Medizin Köln and Labor Tumorgenetik und \\ Zellbiologie, Klinik I für Innere Medizin, Universität zu Köln, Köln/Germany \\ 2 corresponding author: H. Abken, tel: +49-221-478-4130; fax: +49-221-478- \\ 6383, e-mail: Hinrich.Abken@Medizin.uni-koeln.DE
}

Received 15.4.97; revised 26.6.97; accepted 14.7.97 Edited by R.A. Knight

\begin{abstract}
Lymphocytes that proliferate autonomously are thought to be arrested at certain steps in differentiation. Here we demonstrate that autocrine proliferating $B$ cells can be induced to terminal differentiation in the presence of ionomycin plus phorbol dibutyrate. The mature $\mathrm{CD} 23^{\text {high }}$ / CD38 ${ }^{\text {low }} \mathrm{B}$ cell phenotype converts to the $\mathrm{CD} 23^{\text {low }} / \mathrm{CD} 38^{\text {high }}$ plasma cell phenotype associated with increased immunoglobulin secretion and PC1 expression and a loss in surface immunoglobulin. Simultaneously, the cells arrest in proliferation and enter apoptosis at day 10 . The cytokines IL- $1 \alpha$, IL-6, TNF $\alpha$ and $\operatorname{TNF} \beta$ that are required to sustain continuous growth are secreted in substantially increased amounts mediating entry into apoptosis of the proliferating cells. Decrease in IL-10 secretion sustains this process. Our results draw the concept that once plasmacytoid differentiation is initiated, the growth sustaining network of autocrine cytokines is disturbed in a particular fashion depriving appropriate signals to suppress the differentiation associated apoptotic program.
\end{abstract}

Keywords: terminal differentiation; B cell maturation; autocrine growth control; apoptosis

Abbreviations: FACS, fluorescence activated cell sorter; Ig, immunoglobulin; mAb, monoclonal antibody; MTT, 3-(4,5dimehtylthiazol-2-yl)-2,5-diphenyl-tetrazoliumbromide; $\mathrm{PBU}_{2}$, phorbol dibutyrate; PKC, protein kinase C

\section{Introduction}

Normal lymphocytes are regulated by two precisely coordinated, but inversely related, genetic programs: one for proliferation and one for differentiation. The cellular development and homeostasis are maintained by a variety of mechanisms, particularly by positive and negative growth control, apoptosis, and immune selection. Increasing evidences suggest that certain cellular and molecular events make the decision between activation, proliferation, tolerance, and apoptosis in B cells. Among these signals, the extent of cross-linking of the $B$ cell antigen receptor plays a pivotal role providing a necessary but incomplete stimulus that requires additional signals, e.g., coreceptors, cytokines, and B cell-T cell contacts (Cohen, 1993; Krammer et al, 1994; Nemazee, 1993; Nossal, 1994). The ligand binding requirements for growth inhibition of immature B cells, however, are less stringent than those required for mature $\mathrm{B}$ cell activation (Udhayakumar et al, 1991) although extensive hypercross-linking of both surface $\operatorname{lgM}$ and $\operatorname{lgD}$ receptors is capable to induce apoptosis in mature resting B cells (Parry et al, 1994).

Defects in the control mechanisms of this process are likely to contribute to tumor development (Wyllie, 1993; Pardee, 1994; Hoffmann and Liebermann, 1994; Tlsty, 1995). On the other hand, induction of terminal differentiation resulting in programmed cell death may overcome the unlimited growth potential of the cell. This concept is sustained for leukemic/lymphoma cells by several examples: G-CSF and GM-CSF induced differentiation of established HL60 leukemic cells is associated with suppression of growth and clonogenicity (Begley et al, 1987); cytokin-induced differentiation of 4F10 lymphoma cells into immunoglobulin secreting cells is accompanied by growth inhibition (Eckmann et al, 1992); cross-linking of surface IgM inhibits proliferation of B lymphoma cells (Kim et al, 1992a,b) resulting in programmed cell death (Ishigami et al, 1992). B lymphoma cells, however, can either be inhibited or stimulated in proliferation, depending on whether the cells are stimulated with anti-lg antibodies in soluble or immobilized form (van Endert and Moldenhauer, 1992).

In contrast to normal B cells dependent on B cell receptor-stimulation and to tumor derived cells with various defaults in growth control, autocrine dependent $B$ cells autonomously sustain their proliferation by secretion of precisely defined amounts of certain cytokines. From the peripheral blood, we previously established autocrine $B$ cells that continuously proliferate in vitro due to a subtile balanced network composed of the four synergistically acting cytokines IL- $1 \alpha$, IL- 6 , TNF $\alpha$ and TNF $\beta$ (Abken et al, 1992). Whereas autocrine proliferating lymphocytes are thought to be arrested at certain steps within their differentiation pathway, it is unresolved whether these cells can be induced to enter terminal differentiation and, finally, programmed cell death. Here we demonstrate that a substantial calcium influx plus a prolonged activation of protein kinase $\mathrm{C}$ does induce autocrine lymphocytes to convert from a mature $B$ cell phenotype to a plasma cell like phenotype. This step in differentiation is accompanied by growth arrest and entry into programmed cell death due to certain alterations in the autocrine network of cytokines. 


\section{Results}

\section{Autocrine dependent $B$ cells differentiate to plasmacytoid cells in the presence of ionomycin plus phorbol dibutyrate}

The human B lymphocyte clone C-26tB7.3 was previously established from peripheral blood lymphocytes and shown to be autocrine growth dependent (Abken et al, 1992). The cells harbor rearranged immunoglobulin (Ig) gene segments, secrete IgA with monoclonally restricted $\mathrm{H}$ and $\mathrm{L}$ chain classes, and express a panel of surface markers indicative for mature B lymphocytes (Table 1). This phenotype is found stable for more than 2 years of continuous culture.

In the presence of ionomycin $(0.8 \mu \mathrm{g} / \mathrm{ml})$ plus phorbol dibutyrate $\left(\mathrm{PBU}_{2}\right)(3 \mathrm{ng} / \mathrm{ml})$ the cells alter their morphology and attach to the culture dish within $24 \mathrm{~h}$ whereas the untreated cells grow in suspension (Figure 1). Cell staining revealed an increased basophilic cytoplasm and a small nucleus with dispersed, less dense chromatin and a prominent nucleous compared to the untreated cells. Electron microscopic analysis additionally showed a welldeveloped Golgi apparatus and endoplasmic reticulum in contrast to the untreated cells.

In order to characterize the altered phenotype, we monitored certain surface marker antigens that are related to the differentiation program of $B$ lymphocytes. CD19 and CD20 are expressed throughout pre-B and mature B cell ontogeny, whereas CD23 is preferentially found on mitogenstimulated B cells but is absent on plasma cells (Uckun, 1990). Expression of CD54 is found on mature $B$ cells and on plasma cells (Boyd et al, 1989) whereas CD38 is exclusively expressed on pre- $\mathrm{B}$ cells and on plasma cells but not on mature B cells (Uckun, 1990). The adhesion molecule CD11a (LFA-1) is continuously expressed during $B$ cell differentiation although in decreased levels on plasma cells (Ahsmann et al, 1992). The plasma cell antigen PC1 is preferentially expressed on plasma cells (Anderson et al, 1985; Crawford and Ando, 1986). C-26tB7.3 cells were incubated with ionomycin, $\mathrm{PBU}_{2}$, or ionomycin plus $\mathrm{PBU}_{2}$ and were subjected to FACS analyses at day 5 . We found clear phenotypic differences between the parental and the treated cells (Table 1). The expression of CD20, CD23, CD11a (LFA-1), CD79, HLA DR, and surface immunoglobulin (slg) was decreased after treatment with ionomycin

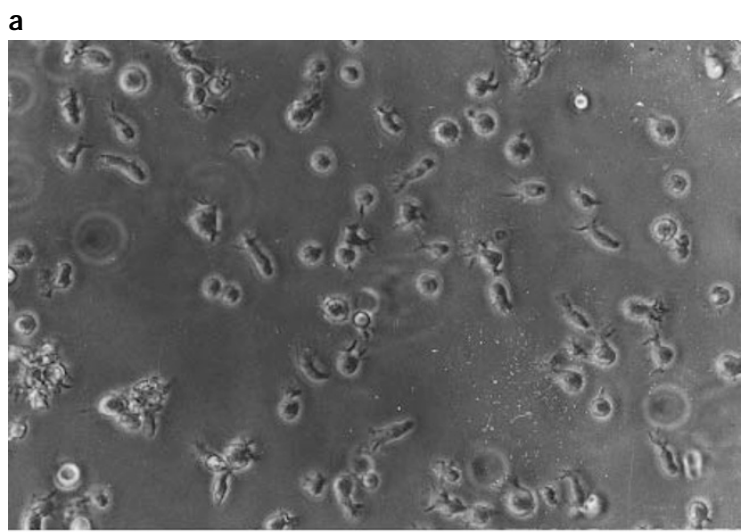

b

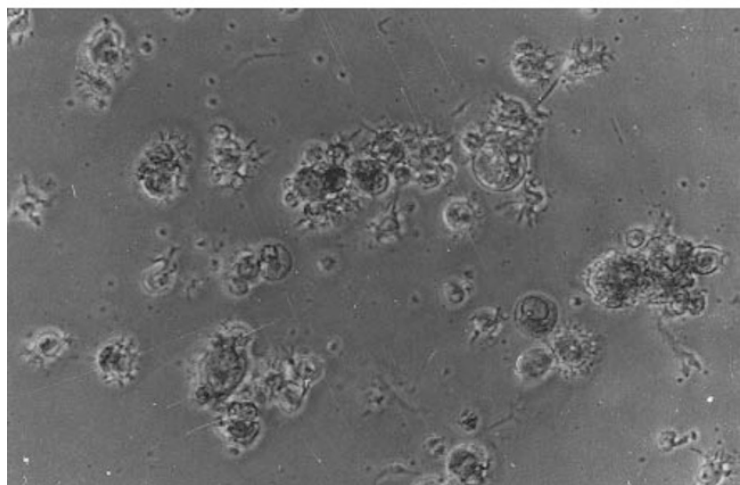

Figure $1 \mathrm{C}-26 \mathrm{tB} 7.3$ cells change their phenotype in the presence of ionomycin plus phorbol dibutyrate $\left(\mathrm{PBU}_{2}\right)$. C-26tB7.3 cells were cultured without supplements (a) or in the presence of ionomycin $(0.8 \mu \mathrm{g} / \mathrm{ml})$ plus $\mathrm{PBU}_{2}$ $(3 \mathrm{ng} / \mathrm{ml})$ for $24 \mathrm{~h}(\mathbf{b})$. Whereas the predominant majority of the parental cells grow in suspension, nearly all treated cells adhere to the culture plate. (microscope magnification: $400 x$ )

Table 1 Expression of surface markers of C-26tB7.3 cells in the presence of ionomycin and phorbol dibutyrate $\left(\mathrm{PBU}_{2}\right)$

\begin{tabular}{|c|c|c|c|c|}
\hline \multirow[b]{2}{*}{ Surface marker } & \multicolumn{4}{|c|}{ Mean fluorescence intensities (MFI \pm S.E.M.) in the presence of } \\
\hline & $--\mathbf{a}$ & lonomycin & $\mathrm{PBU}_{2}$ & Ionomycin plus $\mathrm{PBU}_{2}$ \\
\hline Control & $9 \pm 7$ & $14 \pm 11$ & $7 \pm 5$ & $18 \pm 5$ \\
\hline HLA class I & $400 \pm 55$ & $510 \pm 95$ & $370 \pm 40$ & $620 \pm 90$ \\
\hline CD11a (LFA-1) & $435 \pm 105$ & $220 \pm 80$ & $90 \pm 70$ & $140 \pm 50$ \\
\hline CD19 & $100+14$ & $150+35$ & $110+25$ & $40+22$ \\
\hline CD20 & $1200 \pm 450$ & $800 \pm 100$ & $250 \pm 200$ & $45 \pm 32$ \\
\hline CD21 & $280 \pm 160$ & $300 \pm 120$ & $120 \pm 80$ & $260 \pm 140$ \\
\hline CD23 & $1300 \pm 380$ & $980 \pm 420$ & $340 \pm 275$ & $30 \pm 20$ \\
\hline CD38 & $12 \pm 8$ & $40 \pm 25$ & $55 \pm 30$ & $140 \pm 50$ \\
\hline CD54 (ICAM-1) & $220 \pm 60$ & $150 \pm 90$ & $230 \pm 45$ & $180 \pm 80$ \\
\hline CD74 & $53 \pm 12$ & $75 \pm 21$ & $64 \pm 14$ & $280 \pm 30$ \\
\hline CD79 & $340 \pm 50$ & $270 \pm 60$ & $310 \pm 70$ & $140 \pm 50$ \\
\hline PC1 & $250+30$ & $340+110$ & $280+80$ & $1250+90$ \\
\hline slg & $760 \pm 110$ & $690 \pm 80$ & $580 \pm 80$ & $170 \pm 40$ \\
\hline
\end{tabular}

C-26tB7.3 cells were cultured in the presence of ionomycin $(0.8 \mu \mathrm{g} / \mathrm{ml})$, phorbol dibutyrate $\left(\mathrm{PBU}_{2}\right)(3 \mathrm{ng} / \mathrm{ml})$, or ionomycin $(0.8 \mu \mathrm{g} / \mathrm{ml})$ plus $\mathrm{PBU} 2(3 \mathrm{ng} / \mathrm{ml})$, respectively. At day 6 , the cells were stained by immunofluorescence and mean fluorescence intensities (MFI) were determined by FACS analysis. The experiments were repeated six times and the data are expressed as the mean \pm S.E.M. Control slg surface immunoglobulin. ${ }^{a}$ no additive 
plus $\mathrm{PBU}_{2}$ compared to that of untreated cells (Figure 2). In contrast, CD38, CD74, plasma cell antigen PC1, and HLA class I expression increased after treatment whereas the expression of CD21 and CD54 (ICAM-1) was not altered. The pattern of CD23 and CD38 expression can be used to distinguish activated $B$ cells from plasma cells (Terstappen et al, 1990). Two-color FACS analysis revealed substantial differences between the treated and the untreated cell populations in respect to the coexpression of these antigens (Figure 3 ). Whereas the predominant majority $(>80 \%)$ of the untreated cells expressed high levels of CD23 (CD23 $\left.{ }^{\text {high }}\right)$ and low levels of CD38 (CD38 ${ }^{\text {low }}$ ), the majority $(>80 \%)$ of the treated cells expressed the reciprocal phenotype, i.e., $\mathrm{CD} 23^{\text {low }} / \mathrm{CD} 38^{\text {high }}$. The transition of the cells from the CD23 $3^{\text {high }} / \mathrm{CD} 38^{\text {low }}$ to the $\mathrm{CD} 23^{\text {low }} / \mathrm{CD} 38^{\text {high }}$ phenotype is indicative for plasma cell differentiation (Terstappen et al, 1990). Accordingly, the amount of immunoglobulins (Ig) secreted by C-26tB7.3 cells into the culture supernatant was found increased after treatment with ionomycin plus $\mathrm{PBU}_{2}$ (Figure 4). We furthermore found a twofold increase in the total protein content per cell and a threefold increase in the activity of mitochondrial dehydrogenases per cell (monitored by metabolization of MTT as substrate) indicating increased metabolic activities of the cells (data not shown). This set of analyses was repeated for two additional, autocrine dependent $B$ cell lines (C-28t1/1 $\left(\operatorname{IgG}^{+}\right)$and B-10.15 $\left(\operatorname{lgM}^{+}\right)$) with similar results (data not shown) demonstrating that the observed phenotypic shift is a predominant event in this model.

Incubation of C-26tB7.3 cells with ionomycin $(0.8 \mu \mathrm{g} / \mathrm{ml})$ plus $\mathrm{PBU}_{2}(3 \mathrm{ng} / \mathrm{ml})$ increased threefold the activity of the membrane bound protein kinase $C(P K C)$ after $24 \mathrm{~h}$ compared to the untreated cells (Figure 5). $\mathrm{PBU}_{2}$ alone only transiently raised the PKC activity to about 1.5 -fold values after $30 \mathrm{~min}$ and ionomycin alone did not significantly alter PKC activities in the membrane fraction. Obviously, coincubation of C-26tB7.3 cells with ionomycin plus $\mathrm{PBU}_{2}$ induced a prolonged increase of PKC activities compared to incubation with $\mathrm{PBU}_{2}$ or ionomycin alone, respectively.

Specific inhibition of the PKC activity by chelerythrine $(10 \mu \mathrm{g} / \mathrm{ml})$ prevented differentiation of C-26tB7.3 cells in the presence of ionomycin plus $\mathrm{PBU}_{2}$ as did chelating of extracellular $\mathrm{Ca}^{2+}$ by EGTA (1-10 mM). Incubation with $\mathrm{PBU}_{2}$ alone did not induce plasmacytoid differentiation but altered growth kinetics of autocrine $\mathrm{B}$ cells dependent on the $\mathrm{PBU}_{2}$ concentration: $\leqslant 1 \mathrm{ng} \mathrm{PBU}_{2} / \mathrm{ml}$ increased whereas $\geqslant 3 \mathrm{ng} \mathrm{PBU}_{2} / \mathrm{ml}$ suppressed proliferation of C$26 \mathrm{tB} 7.3$ cells. Activation of protein kinase A by incubation with dibutyryl-cAMP $(25-500 \mu \mathrm{M})$, in contrast to PKC activation, increased cell proliferation but no plasma cell differentiation was recorded (data not shown). We conclude that both a substantial calcium influx and a prolonged increase in PKC activities are required to induce plasmacytoid differentiation of C-26tB7.3 cells.

\section{The autocrine B cells loose autonomous growth stimulation and enter apoptosis after plasmacytoid differentiation}

C-26tB7.3 cells proliferate autonomously for more than 2 years in vitro without detectable growth arrest or senescence. In the presence of ionomycin plus $\mathrm{PBU}_{2}$,
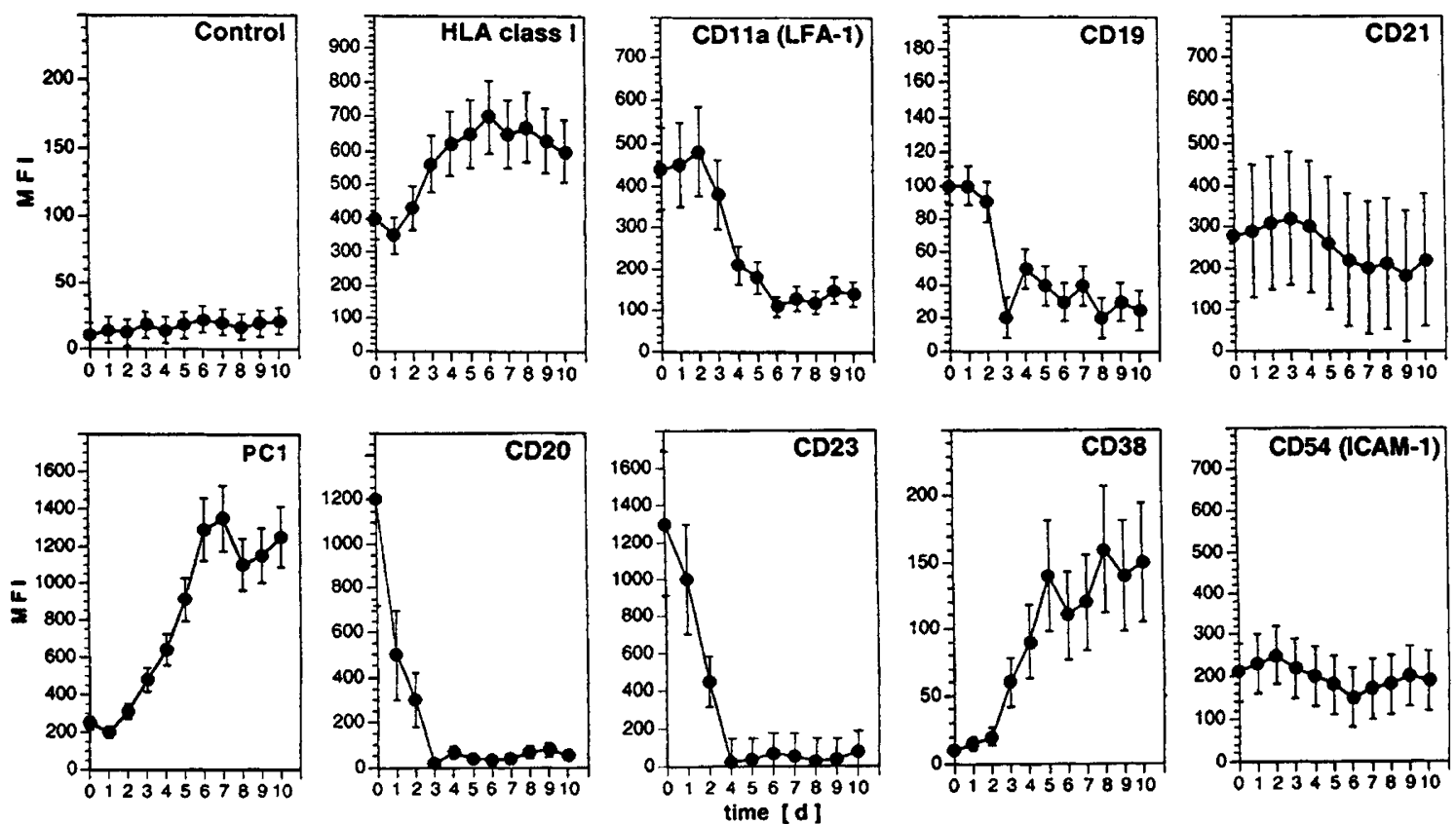

Figure 2 The expression of certain B cell markers is altered after incubation of C-26tB7.3 cells with ionomycin plus phorbol dibutyrate (PBU $)$. C-26tB7.3 cells were incubated in the presence of ionomycin $(0.8 \mu \mathrm{g} / \mathrm{ml})$ plus PBU $2(3 \mathrm{ng} / \mathrm{ml})$ and monitored for the expression of the B cell marker CD11a (LFA-1), CD19, CD20, CD21, CD23, CD38, CD54 (ICAM-1), and PC1. Control specifies immunofluorescence staining with a secondary antibody to indicate the background. The experiments were performed six times and the data are expressed by the mean \pm S.E.M. MFI: mean fluorescence intensity 


\section{medium control}

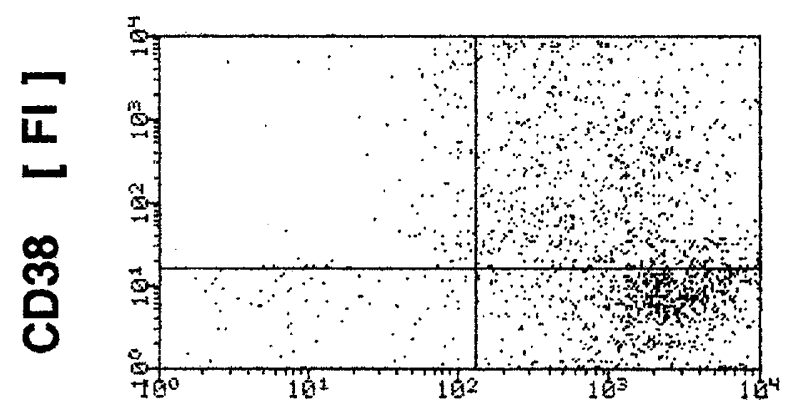

+ ionomycin

+ phorbol dibutyrate

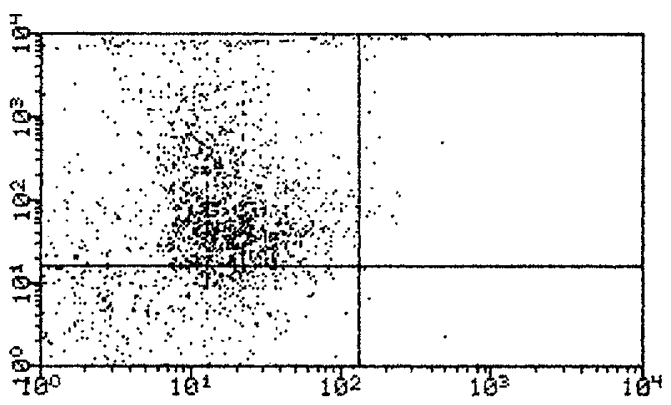

\section{CD23 [ FI ]}
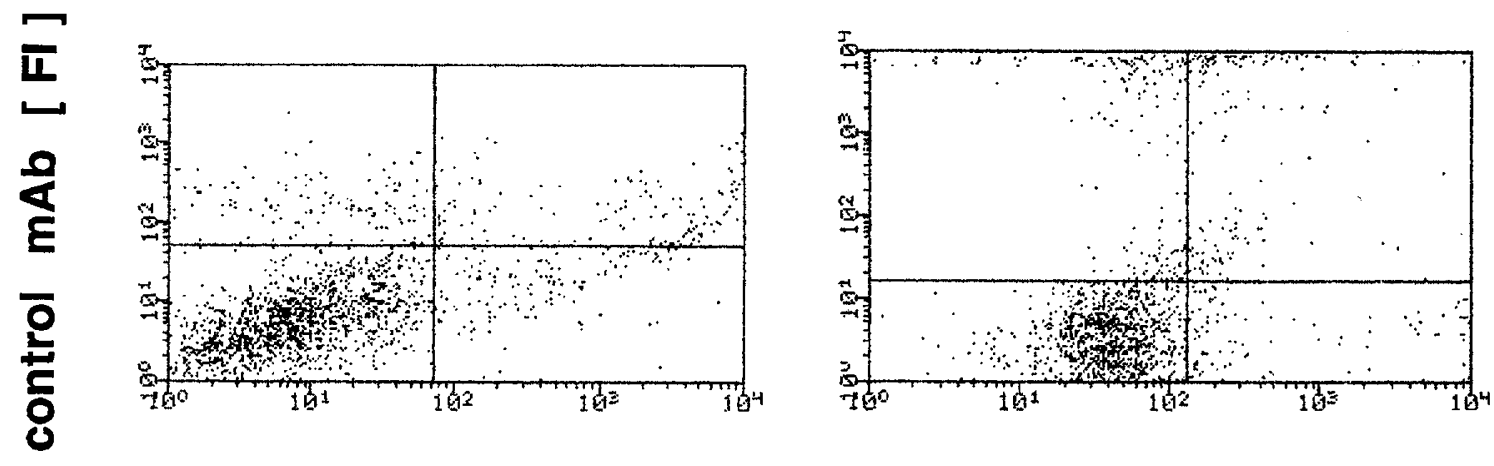

control mAb [ FI ]

Figure 3 Correlated alteration in the expression of CD23 and CD38. C-26tB7.3 cells were cultured without additives or in the presence of ionomycin $(0.8 \mu \mathrm{g} / \mathrm{ml})$ plus $\mathrm{PBU}_{2}(3 \mathrm{ng} / \mathrm{ml})$. At day 4 the cells were stained with fluorescein isothiocyanate(FITC)-conjugated anti-CD23 mAb and with phycoerythrin(PE)-conjugated anti$\mathrm{CD} 38 \mathrm{mAb}$ and were subjected to FACS analysis. Plots representing approximately 5000 gated events are shown from a representative analysis. Controls illustrate the binding of a FITC- and PE-conjugated mAb with irrelevant specificity to monitor unspecific binding to the cells. Fl: fluorescence intensity

however, the number of viable cells decreased to $50 \%$ within 10 days (Figure 6A). Simultaneously, the incorporation of BUdR into nuclei during a 10-h-incubation period decreased from $27 \%$ to less than $2 \%$ of the cells at day 5 indicating a substantial decrease in cycling cells. We moreover found oligonucleosomal fragmented DNA in increasing amounts reaching maximum on day 12-16. This observation is based (i) on electrophoretic separation of cellular DNA after in vitro labelling with $\alpha-{ }^{32} \mathrm{P}-\mathrm{dCTP}$ by the Klenow DNA polymerase reaction (Figure $6 \mathrm{~B}$ ) and (ii) on a sandwich ELISA that detects mobilized nucleosomes in the cytoplasmic fraction of the cells (Figure 6C). The portion of cells with fragmented nuclear DNA rose from background levels at day 4 to $70-80 \%$ at day $12-16$ (Figure 6D) as recorded by in situ labelling of DNA molecule ends by TUNEL techniques. We conclude that after arrest in proliferation in the presence of ionomycin plus $\mathrm{PBU}_{2}$, the cells exhibit a median life span of 10 days and subsequently die by programmed cell death.
C-26tB7.3 cells secrete and re-internalize the cytokines $\mathrm{IL}-1 \alpha, \mathrm{IL}-6, \mathrm{TNF} \alpha$, and TNF $\beta$ that together are required in precisely defined concentrations to sustain continuous proliferation (Abken et al, 1992). In addition, the cells secrete constitutively IL-10 that, however, does not seem to be required for growth in limited dilution cultures. In the presence of ionomycin plus $\mathrm{PBU}_{2}$, the C-26tB7.3 cells secrete substantially increased amounts of IL-1 $\alpha$ (sixfold), IL-6 (ninefold), TNF $\alpha$ (35-fold), and TNF $\beta$ (3.5-fold) into the culture medium compared to the untreated cells. In contrast, secretion of IL-10 dropped to about $20 \%$ the level of the untreated cells (Figure 7).

In order to prove whether the altered concentrations of these cytokines contribute to growth arrest and apoptosis, we supplemented the medium of the autocrine proliferating C-26tB7.3 cells with the recombinant cytokines in those concentrations that we recorded after growth arrest. A series of substitution experiments revealed that addition of $\mathrm{TNF} \alpha(1.7 \mathrm{ng} / \mathrm{ml})$ induces growth arrest to certain degrees. 


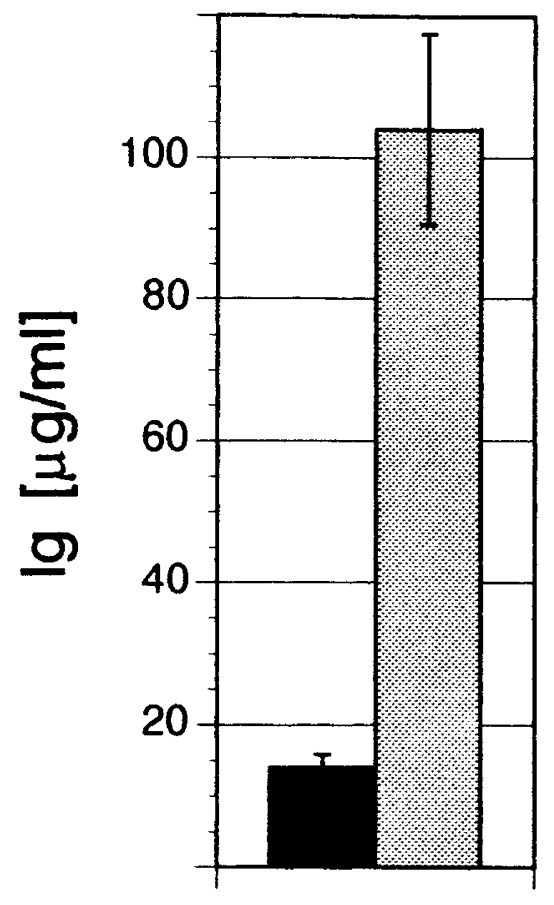

Figure 4 C-26tB7.3 cells secrete increased amounts of immunoglobulins in the presence of ionomycin plus $\mathrm{PBU}_{2}$. C-26tB7.3 cells $\left(2 \times 10^{6} \mathrm{cell} / \mathrm{sl}\right)$ were cultured in medium without additives [0] or in the presence of ionomycin $(0.8 \mu \mathrm{g} / \mathrm{ml})$ plus $\mathrm{PBU}_{2}(3 \mathrm{ng} / \mathrm{ml})$ [ $\square$ ], respectively. At day 4 , the cells were washed and cultured in fresh medium for $24 \mathrm{~h}$. The amount of immunoglobulin (Ig) per ml secreted into the culture supernatant per $24 \mathrm{~h}$ was determined by ELISA and normalized to $2 \times 10^{6}$ viable cells

However, TNF $\alpha(1.7 \mathrm{ng} / \mathrm{ml}), \operatorname{TNF} \beta(7 \mathrm{ng} / \mathrm{ml}), \mathrm{IL}-1 \alpha(150 \mathrm{pg} /$ $\mathrm{ml})$, plus IL-6 $(100 \mathrm{pg} / \mathrm{ml})$ together effectively induced growth arrest of C-26tB7.3 cells (Figure 8). Neutralization of IL-10 by an anti-IL-10 antibody in addition to supplementation with high amounts of IL- $1 \alpha$, IL- 6 , TNF- $\alpha$, plus TNF- $\beta$ increased growth arrest whereas neutralization of IL-10 alone did not alter growth of C-26tB7.3 cells. Addition of IL-10 $(0.2-2 \mathrm{ng} / \mathrm{ml})$, however, did not reverse growth suppression by the four cytokines in high concentrations. No differentiation to a plasmacytoid phenotype was observed after addition of the altered amounts of the cytokines to continuously growing B cells. The substitution experiments demonstrate that the same cytokines that sustain continuous growth mediate growth arrest of autocrine B cells dependent on the cytokine concentration in the culture environment.

\section{Discussion}

The present analysis was performed to prove whether autocrine dependent $B$ cells with unlimited proliferation potential can be induced to terminal differentiation and to apoptosis. Here we demonstrate that in the presence of ionomycin plus phorbol dibutyrate, the phenotype of the ionomycin

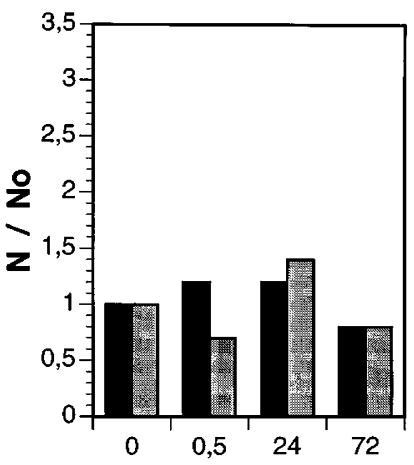

phorbol dibutyrate

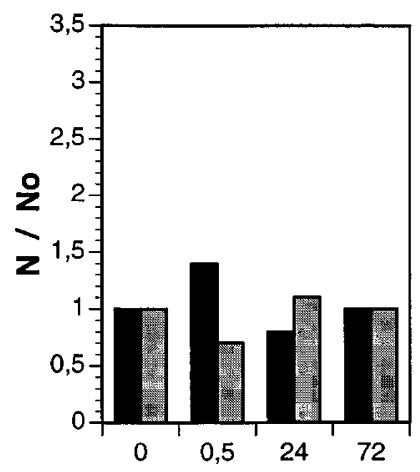

\section{ionomycin plus phorbol dibutyrate}

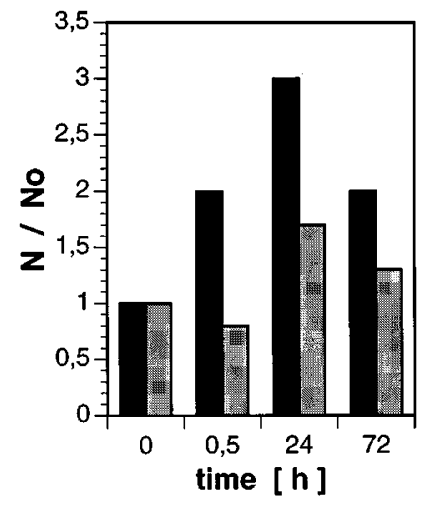

Figure 5 Prolonged increase in the protein kinase $C$ activity in the presence of ionomycin plus phorbol dibutyrate. C-26tB7.3 cells $\left(10^{6} \mathrm{cells} / \mathrm{ml}\right)$ were incubated in Iscove's medium without supplements or in the presence of ionomycin $(0.8 \mu \mathrm{g} / \mathrm{ml})$, phorbol dibutyrate $\left(\mathrm{PBU}_{2}\right)(3 \mathrm{ng} / \mathrm{ml})$, or ionomycin plus $\mathrm{PBU}_{2}$. The activity of the protein kinase $\mathrm{C}$ in the membrane fraction (closed columns) and in the cytoplasmic fraction (open columns), respectively, of the cells in presence of supplements $(\mathrm{N})$ was normalized to the activity of the cells incubated without supplements (No)

mature $B$ cells changes in a particular pattern: a shift from the CD23 $3^{\text {high }} / C D 38^{\text {low }}$ to the $C D 23^{\text {low }} / C D 38^{\text {high }}$ expression profile, increase in $\mathrm{Ig}$ secretion, increased expression of PC1 and CD74, and a loss in surface Ig, CD11a(LFA-1), CD19, and CD20 expression. This particular change in phenotype is indicative for plasma cell differentiation (Terstappen et al, 1990; Anderson et al, 1985; Crawford and Ando, 1986). We recorded the same phenotypic shift in the three autocrine dependent B cell lines tested (C-26tB7.3, B$10.15, \mathrm{C}-28 \mathrm{t} 1 / 1)$ indicating that the plasma cell differentiation is a predominant event in this model. 
Both a substantial calcium influx plus a prolonged stimulation of protein kinase $C$ are required for induction of plasmacytoid differentiation because each ionomycin and $\mathrm{PBU}_{2}$, respectively, did not initiate this process. Since induction of differentiation by $B$ cell receptor ligation generates sustained elevations of intracellular $\mathrm{Ca}^{2+}$ concentrations, it is tempting to speculate that the amplitude and/or duration of $\mathrm{Ca}^{2+}$ signalling may be an
A

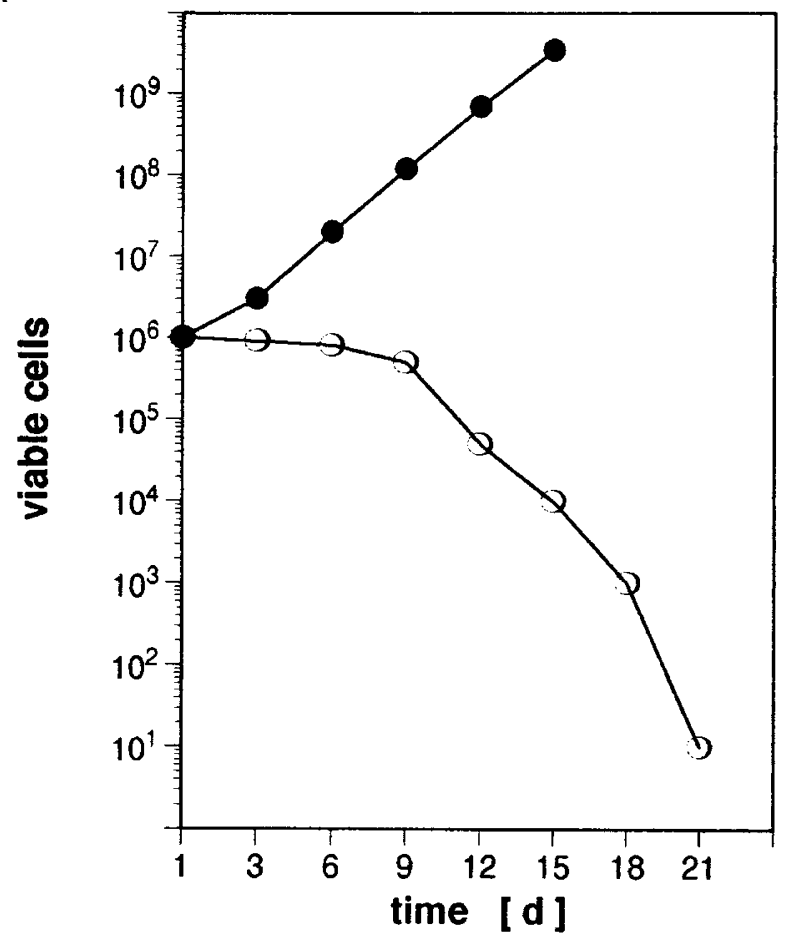

C

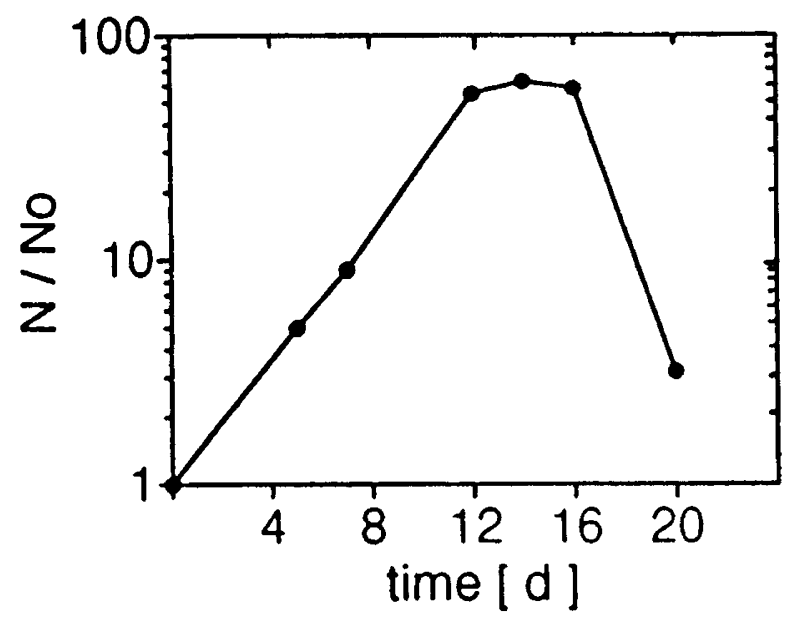

B $\begin{array}{lllll}1 & 2 & 3 & 4 & 5\end{array}$

$\mathrm{kb}$

D

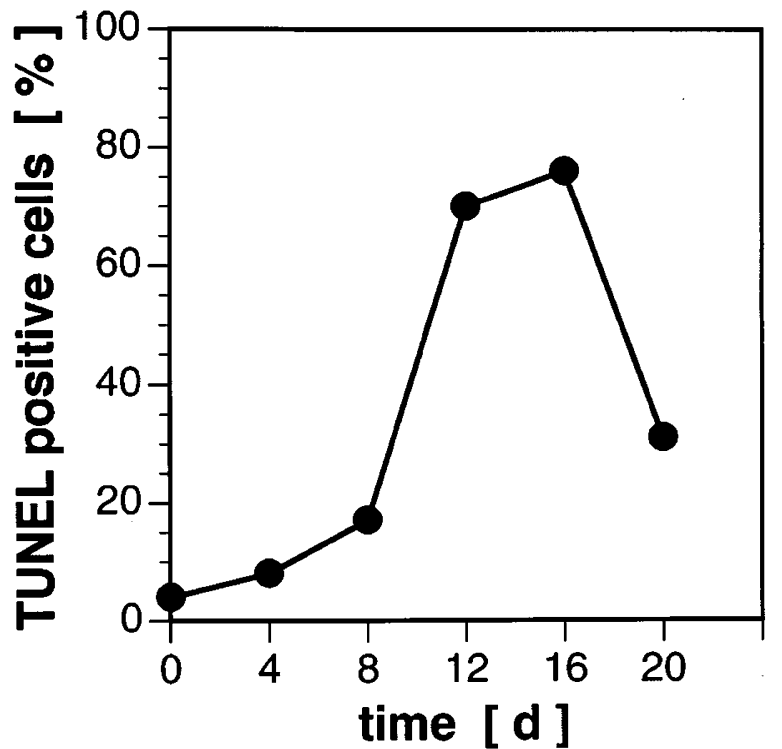

Figure 6 In the presence of ionomycin plus porbol dibutyrate, C-26tB7.3 cells arrest in autonomous proliferation and harbor oligonucleosomal fragmented chromosomal DNA. (A) C-26tB7.3 cells $\left(10^{6} \mathrm{cells} / \mathrm{ml}\right)$ were incubated in Iscove's medium without supplements [-0] or in presence of ionomycin (0.8 $\left.\mu \mathrm{g} / \mathrm{ml}\right)$ plus $\mathrm{PBU}_{2}(3 \mathrm{ng} / \mathrm{ml})[\mathrm{O}-\mathrm{O}]$. The number of viable cells was determined by the trypan blue exclusion assay. (B) C-26tB7.3 cells $\left(10^{6}\right.$ cells/ml) were cultured without additive (lane 1), or in presence of ionomycin $(0.8 \mu \mathrm{g} / \mathrm{ml})$ plus $\mathrm{PBU}_{2}(3 \mathrm{ng} / \mathrm{ml})$ (lanes $\left.2-5\right)$. At day 3 (lane 2), 7 (lane 3), 12 (lane 4$)$, and 16 (lane 5), respectively, cells were lysed and high molecular weight DNA was sedimented by centrifugation. Fragmented DNA in the supernatant was labelled with $\alpha-{ }^{32} \mathrm{P}$-dCTP by Klenow polymerase reaction, separated by agarose gel electrophoresis, and visualized by autoradiography. (C) Oligonucleosomal DNA-histone complexes that accumulate during apoptotic degradation of chromosomal DNA were monitored by a sandwich ELISA as described in Materials and Methods. Briefly, the DNAhistone complexes within the supernatant of a cellular lysate were captured by an anti-DNA antibody anchored onto a microwell plate and were quantitatively monitored by a peroxidase-coupled anti-histone antibody. Recordings of cells incubated with ionomycin $(0.8 \mu \mathrm{g} / \mathrm{ml}) \mathrm{plus} \mathrm{PBU_{2 }}(3 \mathrm{ng} / \mathrm{ml})[\mathrm{N}]$ were normalized to those of an untreated control culture $\left[\mathrm{N}_{0}\right.$ ]. (D) C-26tB7.3 cells were incubated in the presence of ionomycin $(0.8 \mu \mathrm{g} / \mathrm{ml}) \mathrm{plus}$ PBU $2(3 \mathrm{ng} / \mathrm{ml})$. By means of the terminal transferase reaction in presence of FITC-dUTP (TUNEL technique) and fluorescence microscopy, cells in apoptosis were visualized. The portion of TUNEL positive cells from total number of cells (\%) is recorded 

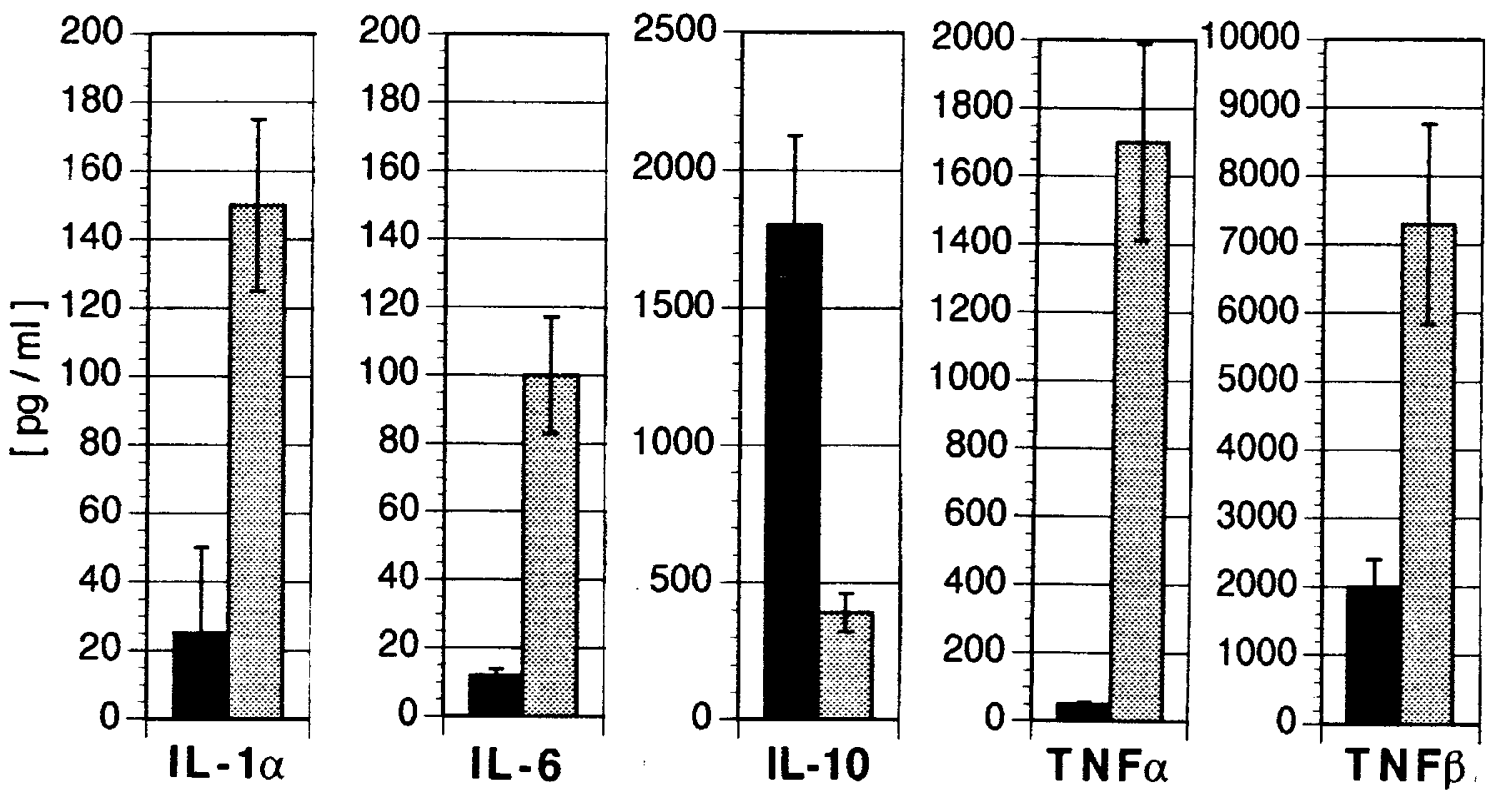

Figure 7 C-26tB7.3 cells secrete altered amounts of cytokines into the culture medium after induction of the plasmacytoid phenotype. C-26tB7.3 cells (10 ${ }^{6}$ cells/ $\mathrm{ml}$ ) were cultured in Iscove's DME medium without additives [ $\mathbf{\square}$ ], or in presence of ionomycin $(0.8 \mu \mathrm{g} / \mathrm{ml}) \mathrm{plus} \mathrm{PBU}_{2}(3 \mathrm{ng} / \mathrm{ml})$ [ $\square$ ], respectively. At day 3 , the cells were washed, plated in fresh culture medium $\left(10^{6}\right.$ cells per $\left.\mathrm{ml}\right)$ for $24 \mathrm{~h}$, and the amount of the specified cytokines in the culture supernatant were determined by ELISA. The experiment was repeated five times and the mean \pm S.E.M. is given. The medium background was below detection limit of the assay

important parameter in the biological response and in the induction of apoptosis of B cells. Although this proposal seems reasonable in view of the known susceptibility of lymphocytes to $\mathrm{Ca}^{2+}$ ionophore-induced apoptosis, an additional prolonged PKC stimulation is here shown to be required to contribute to the induction of differentiation and apoptosis of autocrine B cells. In B lymphoma, B-CLL cells, and Burkitt's lymphoma cell lines, an imbalance in sigdependent signalling pathways, which could favour sustained intracellular $\mathrm{Ca}^{2+}$ increase, has been proposed to be causal for the apoptotic death (Benhamou et al, 1994; McConkey et al, 1991; Knox et al, 1992).

Whereas elevation of the cytosolic $\mathrm{Ca}^{2+}$ level represents a common trigger for apoptosis in various cells (McConkey and Orrenius, 1995), in some model systems, however, elevation of the cytosolic $\mathrm{Ca}^{2+}$ level has been shown to inhibit apoptosis. In IL-3 dependent hematopoietic progenitor cells, the calcium ionophore A23187 suppresses apoptosis (Rodriguez-Tarduchy et al, 1992, 1994) whereas phorbol esters protect the IL-3 dependent cells from apoptosis (Rajotte et al, 1992). The effect of the ionophore in that system is due to secretion of IL-4 which in turn promotes survival (Rodriguez-Tarduchy et al, 1994).

Autonomous proliferation of the C-26tB7.3 cells depends on the secretion of IL- $1 \alpha, \mathrm{IL}-6, \mathrm{TNF} \alpha$, and $\mathrm{TNF} \beta$ in subtile balanced amounts (Abken et al, 1992). After induction of plasmacytoid differentiation, the cells arrest in proliferation and secrete these cytokines in substantially increased amounts. When added in those altered concentrations to the untreated proliferating C-26tB7.3 cells, the same cytokines that are required for autocrine growth stimulation mediate growth arrest indicating that the potential of the cytokines to sustain continuous proliferation is strictly dose dependent. We speculate that the implementation of an underlying cell death program is inhibited as long as the cytokine network of autocrine stimulation is available to suppress the apoptotic process. In the induction of growth arrest of autocrine B cells, decrease in IL-10 secretion acts synergistically with increase in IL- $1 \alpha, \mathrm{IL}-6, \mathrm{TNF} \alpha$, and TNF $\beta$ secretion because neutralization of IL-10 enhanced growth arrest and cell death. Addition of IL-10, however, did not prevent apoptosis of the cells in presence of ionomycin plus $\mathrm{PBU}_{2}$. This is in accordance to the report that in lymphoma cells IL-10 expression does not protect from calciummediated apoptosis (Levy and Brouet, 1994; Liu et al, 1991). In B-CLL cells, IL-10 exhibits proapoptotic activities (Fluckiger et al, 1994) whereas the apoptosis of germinal center B cells is prevented by IL-10 (Levy and Brouet, 1994).

Several contradictory observations imply that the situation of re-entry into the differentiation and apoptosis pathway seems to be different in the autocrine nontumorigenic $\mathrm{B}$ cells compared to tumorigenic B lymphoma cells. In lymphoma cells, TNF $\alpha(1-10 \mathrm{ng} / \mathrm{ml})$ protects against calcium dependent apoptosis but does not potentiate the protective effect of phorbol esters on ionomycin-induced apoptosis (Genestier et al, 1995). Treatment of lymphoma cells with ionomycin results in apoptosis that can be prevented by phorbol ester mediated PKC activation (Ishigami et al, 1992; Knox et al, 1992; Bonnefoy-Berard et al, 1994; Kim et al, 1992a,b; Vazquez et al, 1991). In B lymphoma cells insufficient PKC activation is suggested to be related to slg-induced growth inhibition and apoptotic death (Benhamou et al, 1990; Sarthou et al, 
IL-1 $\alpha$

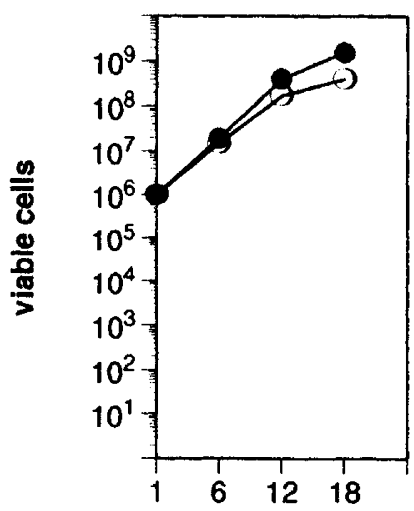

$\frac{0}{\overline{0}}$
$\frac{0}{0}$
$\frac{0}{2}$
IL-6

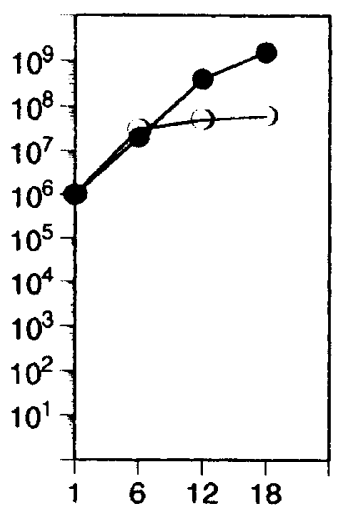

anti IL-10 mAb

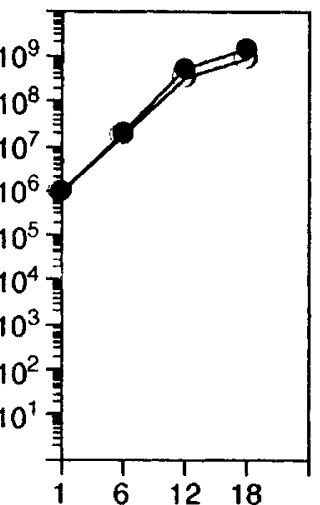

TNF $\alpha$

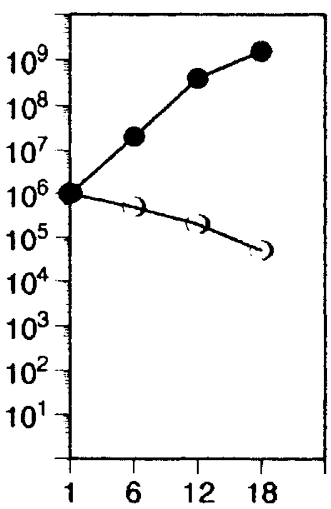

$$
\text { IL }-1 \alpha+\text { IL- } 6+
$$$$
\text { TNF } \alpha+\text { TNF } \beta
$$

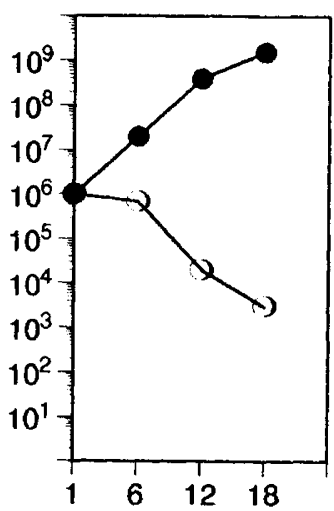

TNF $\beta$

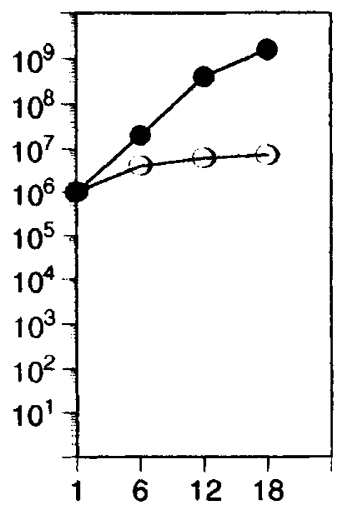

$\mathrm{IL}-1 \alpha+\mathrm{IL}-6+$ TNF $\alpha+$ TNF $\beta+$ anti IL-10 mAb

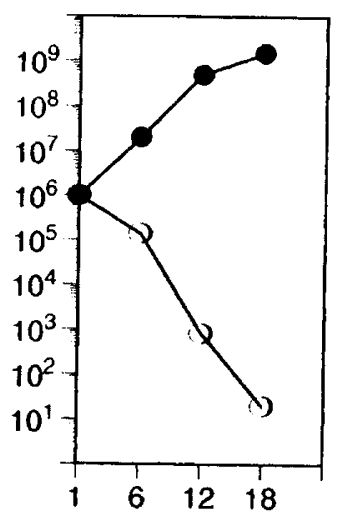

time [d]

Figure 8 Continuous growth of C-26tB7.3 cells is inhibited in the presence of altered concentrations of the cell secreted cytokines. The autonomously proliferating C-26tB7.3 cells $\left(10^{6}\right.$ cells $\left./ 10 \mathrm{ml}\right)$ were incubated in Iscove's medium without additives [-0] or supplemented with the recombinant human cytokines in those concentrations that were recorded after incubation with ionomycin $(0.8 \mu \mathrm{g} / \mathrm{ml})$ plus $\mathrm{PBU}_{2}(3 \mathrm{ng} / \mathrm{ml})$ (cf. Figure 7$)[\bigcirc-\bigcirc]: \mathrm{TNF} \alpha(1.7 \mathrm{ng} / \mathrm{ml}), \mathrm{TNF} \beta(7 \mathrm{ng} / \mathrm{ml}), \mathrm{IL}-1 \alpha$ $(150 \mathrm{pg} / \mathrm{ml})$, and IL-6 $(100 \mathrm{pg} / \mathrm{ml})$. Alternatively or additionally, an anti IL-10 antibody $(10 \mu \mathrm{g} / \mathrm{ml})$ was added. The number of viable cells was determined by trypan blue assay

1989). This is in agreement with the observation that PKC activation rescued several lymphoma cells from anti-lginduced cell death: Peyer's patch B-cells (Motyka et al, 1993), Burkitt's lymphoma cells (Knox et al, 1992), Ramos cells (Valentine and Licciardi, 1992), and the immature BKS-2 lymphoma cells (Muthukkumar et al, 1993). Moreover, PKC activation prevents germinal center B cells (Knox et al, 1992), ilial Peyer's patch B cells (Motyka et al, 1993), and resting splenic B cells (Illera et al, 1993) from spontaneous apoptosis. These studies suggest that insufficient PKC activities may be at least partially responsible for both antigen-induced apoptosis in immature $B$ cells and for apoptotic death-by-default of mature B cells deprived of antigenic stimulation. Since sustained PKC activation blocks the ability of anti-lg antibodies to induce $\mathrm{Ca}^{2+}$ mobilization in $\mathrm{B}$ cells and in lymphomas (Bijsterbosch and Klaus, 1987; Gold and deFranco, 1987), low level PKC activation might result in sustained intracellular $\mathrm{Ca}^{2+}$ elevation which in turn would trigger the apoptosis program.

Some discrepancies in the effect of calcium influx plus PKC stimulation to $B$ cells at various stages of differentiation and neoplastic transformation may moreover reflect differential susceptibilities of the cells to these signals. This may be due to multiple PKC isoforms, which may differentially respond to antigenic stimulation and vary in 
substrate specificity and activation requirements (Marquez et al, 1992). Regarding susceptibility of B cells to differentiation and apoptosis signals, it is unresolved, however, whether or not PKC isoform expression is developmentally regulated.

\section{Materials and Methods}

\section{Cell lines}

The B lymphocyte lines C-26tB7.3, C-28t1/1 and B10.15 were independently established from peripheral blood lymphocytes as described (Abken et al, 1993). Cells were cultured in Iscove's DME medium supplemented with insulin $(0.1 \mathrm{U} / \mathrm{ml})$, transferrin $(1 \mu \mathrm{g} / \mathrm{ml})$, pyruvate (1 mM), oxaloacetic acid (1 mM), HEPES (20 mM), and 10\% fetal calf serum (FCS) ('Myoclone' plus serum, Gibco BRL, Paisley, Scotland). To monitor the cell viability, metabolic degradation of 3(4,5-dimethylthiazol-2-yl)-2,5-diphenyl-tetrazoliumbromide (MTT) was colorimetrically determined (Mosmann, 1983).

\section{Assays for apoptotic cells}

Cells $\left(10^{7}\right)$ were lysed in $500 \mu$ of lysis buffer $(5 \mathrm{mM}$ Tris- $\mathrm{HCl}, \mathrm{pH} 8.0$, $1 \mathrm{mM}$ EDTA, $0.5 \%$ Triton $\mathrm{X}-100$ ) for $15 \mathrm{~min}$ at $4^{\circ} \mathrm{C}$ and high molecular weight DNA was sedimented by centrifugation at $10000 \times g$ for $20 \mathrm{~min}$. The DNA fragments within the supernatant were radioactively labelled with $\alpha{ }^{32} \mathrm{P}$-dCTP by terminal transferase reaction and analyzed by agarose gel electrophoresis. Alternatively, the nucleosomal DNA fragments were captured by an anti-DNA antibody anchored onto a microwell plate and quantitatively monitored by a PODconjugated anti-histone antibody ('cell death detection assay', Boehringer Mannheim, Mannheim, Germany). For in situ detection of apoptotic cells, cells on cytospin slides were fixed, permeabilized, and incubated in the presence of terminal desoxynucleotidyl transferase and FITC-labelled dUTP (TUNEL technique) (Gavrieli et al, 1992). After washing, the cells with accumulation of chromosomal DNA breaks are detected by fluorescence microscopy.

\section{FACS analyses}

Cells were labelled with mouse monoclonal antibodies specific for the human CD11a, CD19, CD20, CD21, CD23, CD38, CD54, CD74, CD79 antigen, respectively, conjugated with FITC or PE. Fluorescence analyses were performed on a FACScan (Becton-Dickinson, Mountain View, Cal.).

\section{Cytokine detection}

Cell-free culture supernatant was obtained from a $24 \mathrm{~h}$ culture of cells seeded at $10^{6}$ cells per $\mathrm{ml}$. The concentration of the particular cytokine was monitored by ELISA tests (TNF $\alpha$ and IL- 6 ELISA from Boehringer Mannheim, Mannheim, Germany; TNF $\beta$, IL- $1 \alpha$, and IL- $1 \beta$ ELISA test from BB British Biotechnology, Abingdon, U.K.; IL-10 ELISA test from Biosource, Camarillo, Cal.).

\section{Analysis of the PKC activity (Casnellie, 1991)}

Cells $\left(5 \times 10^{6}\right)$ were washed in PBS containing $1 \mathrm{mM}$ sucrose and resuspended in $500 \mu \mathrm{l}$ of lysis buffer (Tris $\mathrm{HCL}(20 \mathrm{mM}), \mathrm{pH} 7.5$, sucrose $(330 \mathrm{mM})$, EDTA $(2 \mathrm{mM})$, EGTA $(0.5 \mathrm{mM})$, PMSF (2 mM). The cells were lysed by ultra sonication at $4^{\circ} \mathrm{C}$ and the lysate centrifuged at $10000 \times g$ for $30 \mathrm{~min}$. The supernatant contains the cytoplasmic fraction, the sediment the membrane fraction. The sediment was stirred for $1 \mathrm{~h}$ in lysis buffer, Triton X-100 (1\%) at $4^{\circ} \mathrm{C}$ and subsequently centrifuged at $10000 \times g$ for $30 \mathrm{~min}$ to obtain the cleared membrane fraction. To monitor the PKC activity, cytoplasmic or membrane fraction $(5 \mu \mathrm{l})$, respectively, was incubated in $100 \mu \mathrm{l}$ of reaction buffer $\left(20 \mathrm{mM}\right.$ Tris- $\mathrm{HCl}, \mathrm{pH} 7.5,10 \mathrm{mM} \mathrm{MgCl}_{2}$, $0.5 \mathrm{mM} \mathrm{CaCl}_{2}, 0.25 \mu \mathrm{g} / \mathrm{ml}$ bovine serum albumin) in presence of 1,2-dioeoyl-sn-glycerol (2 $\mu \mathrm{g})$, phosphatidylserine $(10 \mu \mathrm{g})$, the synthetic PKC substrate Ac-MBP(4-14) $(25 \mu \mathrm{M})$ (Boehringer Mannheim, Mannheim, Germany), and of $\gamma^{32} \mathrm{P}$-dATP $(0.5 \mu \mathrm{Ci})$ for $12 \mathrm{~min}$ at $30^{\circ} \mathrm{C}$. The reaction mixture was fixed onto P80 paper and subsequently washed in phosphoric acid $(0.1 \mathrm{M})$ and in ethanol $(96 \%)$. Radioactivity bound to the paper was determined by scintillation spectrometry.

\section{Acknowledgements}

We would like to thank $\mathrm{Dr} \mathrm{K}$ Willecke (Institut für Genetik, Universität Bonn, Bonn, Germany) for stimulating discussions during the initial phase of this work. This work was supported by the Deutsche Forschungsgemeinschaft, Bonn, Germany, the Boehringer Mannheim GmbH, Mannheim, Germany, and the Bundesministerium für Forschung und Technologie, Bonn, Germany, through the Zentrum für molekulare Medizin Köln.

\section{References}

Abken $\mathrm{H}$, Fluck $\mathrm{J}$ and Willecke $\mathrm{K}$ (1992) Four cell-secreted cytokines act synergistically to maintain long term proliferation of human $B$ cell lines in vitro. J. Immunol. 149: 2785-2794

Abken H, Hegger R, Bützler C and Willecke K (1993) Short DNA sequences from the cytoplasm of mouse tumor cells induce immortalization of human lymphocytes in vitro. Proc. Natl. Acad. Sci. USA 90: 6518-6522

Ahsmann EJM, Lokhorst HM, Dekker AW and Bloem AC (1992) Lymphocyte function-associated antigen-1 expression on plasma cells correlates with tumor growth in multiple myeloma. Blood 79: 2068-2075

Anderson KC, Boyd AW, Fisher DC, Slaughenhoupt B, Groopman JE, O'Hara CJ, Daley JF, Schlossmann SF and Nadler LM (1985) Isolation and functional analysis of human B-cell populations. I. Characterization of the $\mathrm{B} 1+\mathrm{B} 2+$ and B1+B2 - subsets. J. Immunol. 134: 820-827

Begley CG, Metcalf D and Nicola NA (1987) Purified colony stimulating factors (GCSF and GM-CSF) induce differentiation in human HL60 leukemic cells with suppression of clonogenicity. Int. J. Cancer 39: 99-105

Benhamou LE, Cazenave P-A and Sathou P (1990) Anti-immunoglobulins induce death by apoptosis in WEHI-231 B lymphoma cells. Eur. J. Immunol. 20: 14051407

Benhamou LE, Watanable T, Kitamura B, Cazenave P-A and Sarthou P (1994) Signaling properties of anti-immunoglobulin resistant variants of WEHI-231. Eur. J. Immunol. 24: 1993-1999

Bijsterbosch MK and Klaus GGB (1987) Tumor-promoting phorbol esters suppress receptor-stimulated inositol phospholipid degradation and $\mathrm{CA}^{2+}$ mobilization in mouse lymphocytes. Eur. J. Immunol. 17: 113-118

Bonnefoy-Berard N, Genestier L, Flacher M and Revillard JP (1994) The phosphoprotein phosphatase calcineurin controls calcium-dependent apoptosis in B cell lines. Eur. J. Immunol. 24: 325-329

Boyd AW, Dunn SM, Fecondo JV, Culvenor JG, Dührsen U, Burnes GF and Wawryk SO (1989) Regulation of expression of a human intracellular adhesion molecule (ICAM-1) during lymphohematopoietic differentiation. Blood 73: 1896-1903

Casnellie JE (1991) Assay of protein kinases using peptides with basic residues for phosphocellulose binding. Methods Enzymol. 200: 115-120

Cohen JJ (1993) Apoptosis. Immunol. Today 14: 126-130

Crawford DH and Ando I (1986) EB virus induction is associated with B-cell maturation. Immunology 59: 405-409

Eckmann L, Morzycka-Wroblewska E, Smith JR and Kagnoff MF (1992) Cytokineinduced differentiation of IgA B cells: studies using an IgA expressing B-cell lymphoma. Immunol. 76: 235-241 
Fluckiger AC, Drand I and Banchereau J (1994) Interleukin 10 induces apoptotic cell death of B-chronic lymphocytic leukemia cells. J. Exp. Med. 179: 91-99

Gavrieli Y, Sherman Y and Ben-Sasson SA (1992) Identification of programmed cell death in situ via specific labeling of nuclear DNA fragmentation. J. Cell Biol. 119: 493-501

Genestier L, Bonnefoy-Berard N, Rouault JP, Flacher M and Revillard JP (1995) Tumor necrosis factor- $\alpha$ up-regulates Bcl-2 expression and decreases calciumdependent apoptosis in human B cell lines. Int. Immunol. 7: 533-540

Gold MR and DeFranco AL (1987) Phorbol esters and dioctanoylglycerol clock antiIgM-stimulated phosphoinositide hydrolysis in the murine B cell lymphoma WEHI-231. J. Immunol. 138: 868-876

Hoffmann B and Liebermann DA (1994) Molecular controls of apoptosis: differentiation/growth arrest primary response genes, proto-oncogenes, and tumor suppressor genes as positive and negative modulators. Oncogene 9: $1807-1812$

Illera VA, Perandones DE, Stunz LL, Mower DA and Ashman RF (1993) Apoptosis in splenic B-lymphocyte regulation by protein kinase C and IL-4. J. Immunol. 151: $2965-2973$

Ishigami T, Kim K-M, Horiguchi Y, Higaki Y, Hata D, Heike T, Katamura K, Mayumi M and Mikawa H (1992) Anti-lgM antibody-induced cell death in a human B lymphoma cell line, B104, represents a novel programmed cell death. J. Immunol. 148: 360-368

Kim K-M, Ishigami T, Hata D, Higaki Y, Morita M, Yamaoka K, Mayumi M and Mikawa H (1992a) Anti-IgM but not anti IgD antibodies inhibit cell division of normal human mature B cells. J. Immunol. 148: 29-34

Kim K-M, Ishigami T, Hata D, Yamaoka K, Mayumi M and Mikawa H (1992b) Regulation of cell division of mature $B$ cells by ionomycin and phorbol ester. J. Immunol. 148: 1797-1803

Knox KA, Finney M, Milner AE, Gregory CD, Wakelam M, Michell RH and Gordon J (1992) Second-messenger pathways involved in the regulation of survival in germinal-centre B cells and in Burkitt Lymphoma lines. Int. J. Cancer 52: 959 966

Krammer PH, Behrmann I, Daniel P, Dhein J and Debatin K-M (1994) Regulation of apoptosis in the immune system. Curr. Opin. Immunol. 6: 279-289

Levy Y and Brouet JC (1994) Interleukin-10 prevents spontaneous death of germinal center B cells by induction of Bcl-2 protein. J. Clin. Invest. 93: 424-428

Liu Y-J, Cairns JA, Holder MJ, Abbot SD, Jansen KU, Bonnefoy Y-Y, Gordon J and MacLennan ICM (1991) Recombinant 25-kDa CD23 and interleukin $1 \alpha$ promote the survival of germinal center B cells: evidence for bifurcation in the development of centrocytes rescued from apoptosis. Eur. J. Immunol. 21: $1107-1114$

Marquez C, Martinez C, Kroemer Gand Bosca L (1992) Protein kinase-C isoenzymes display differential affinity for phorbol esters. Analysis of phorbol ester receptors in B-cell differentiation. J. Immunol. 149: 2560-2568

McConkey DJ and Orrenius S (1995) Calcium and cyclosporin A in the regulation of apoptosis. Curr. Top. Microbiol. Immunol. 200: 95-105

McConkey DJ, Aguilar-Santelisis M, Hartzell P, Eriksson I, Mollstedt H, Orrenius S and Jondal M (1991) Induction of DNA fragmentation in chronic B-lymphocytic leukemia cells. J. Immunol. 146: 1072-1076

Mosmann T (1983) Rapid colorimetric assay for cellular growth and survival: application to proliferation and cytotoxicity assays. J. Immunol. Methods 65:5563
Motyka B Griebel PJ and Reynolds JD (1993) Agents that activate protein kinase C rescue sheep ileal Peyer's patch B-cells from apoptosis. Eur. J. Immunol. 23: $1314-1321$

Muthukkumar S, Udhayakumar V and Bondada S (1993) Elevation of cytosolic calcium is sufficient to induce growth inhibition in a B-cell lymphoma. Eur. J. Immunol. 23: 2419-2426

Nemazee DA (1993) Promotion and prevention of autoimmunity by B-lymphocytes. Curr. Opin. Immunol. 5: 866-872

Nossal GJV (1994) Negative selection of lymphocytes. Cell 76: 229-239

Pardee AB (1994) Growth dysregulation in cancer cells. Adv. Cancer Res. 65: 213 227

Parry SL, Hasbild J, Holman M and Klaus GGB (1994) Hypercross-linking surface $\lg \mathrm{M}$ or $\operatorname{lgD}$ receptors on mature $\mathrm{B}$ cells induces apoptosis that is reversed by costimulation with IL-4 and anti-CD40. J. Immunol. 152: 2821-2829

Rajotte D, Haddad P, Haman A, Cragoe EF Jr and Hoang T (1992) Role of proteinkinase $\mathrm{C}$ and the $\mathrm{Na}^{+} / \mathrm{H}^{+}$antiporter in suppression of apoptosis by granulocyte macrophage colony-stimulating factor and interleukin-3. J. Biol. Chem. 267: 9980-9987

Rodriguez-Tarduchy G, Collins M and Lopez-Rivas A (1994) Regulation of apoptosis in interleukin-3-dependent hemapoietic cells by interleukin-3 and calcium ionophores. EMBO J. 9: 2997-3002

Rodriguez-Tarduchy G, Malde P, Lopez-Rivas A and Collins MKL (1992) Inhibition of apoptosis by calcium ionophores in IL-3-dependent bone marrow cells is dependent upon production of IL-4. J. Immunol. 148: 1416-1422

Sarthou P, hery-Toulmé N and Cazenave P-A (1989) Membrane IgM cross-linking is not coupled to protein kinase $\mathrm{C}$ translocation in WEHI-231 B lymphoma cells. Eur. J. Immunol. 19: 1247-1252

Terstappen LWMM, Johnsen S, Seger-Nolten MJ and Loken MR(1990) Identification and characterization of plasma cells in normal human bone marrow by highresolution flow cytometry. Blood 76: 1739-1747

TIsty TB (1995)Cell cycle control and genomic instability. Cancer Metastasis Rev. 14: $1-2$

Uckun F (1990) Regulation of human B-cell ontogeny. Blood 76: 1908-1923

Udhayakumar V, Muthukkumar S and Subbarao B (1991) Cyclosporin-A blocks surface IgM-mediated growth inhibition in an immature B-lymphoma, BKS-2. Eur. J. Immunol. 21: 2605-2608

Valentine MA and Licciardi KA (1992) Rescue from anti-IgM-induced programmed cell death by the B-cell surface proteins CD20 and CD40. Eur. J. Immunol. 22: $3141-3148$

Van Endert PM and Moldenhauer G (1992) Inhibitory and stimulatory signaling via immunoglobulin receptors. Dichotomous responses elicited in clonal B-cell populations. Eur. J. Immunol. 22: 1229-1235

Vazquez A, Auffredou MT, Chaouchi N, Taieb J, Sharma S, Galanoud P and Leca G (1991) Differential inhibition of interleukin 2-and interleukin 4-mediated human B cell proliferation by ionmycin: a possible regulatory role for apoptosis. Eur. J. Immunol. 21: 2311-2316

Wyllie AH (1993) Apoptosis (The 1992 Frank Rose Memorial Lecture) Br. J. Cancer 67: 205-208 